INOVASI, 14 (2) 2018, 98-112

http://journal.feb.unmul.ac.id/index.php/INOVASI

\title{
Risk management of logistic department of electricity company
}

\section{Erdiyan Krisnadi Hasda ${ }^{1}$, Erman Sumirat ${ }^{2}$}

School of Business and Management Institut Teknologi Bandung, Indonesia

${ }^{1}$ Email: 1erdiyan.krisnadi@sbm-itb.ac.id

${ }^{2}$ Email: erman.sumirat@sbm-itb.ac.id

\begin{abstract}
This study is conducted to carry out the risk management process in the logistics department of the electricity company unit, which has the main duties in managing electricity transmission assets, controlling investment and logistics transmission, and maintaining transmission assets. The risk management process in this study was prepared as a step in shaping the risk profile of business processes in the logistics field to avoid the failure of business processes that resulted in unavailbility of logistics material, which could impact the electricity transmission. This study uses the AS/NZS ISO 31000:2009 Risk Management Standard framework. Calculation of risk priorities is using Analytical Hierarchy Process, based on a questionnaire to experts in the field of company logistics. From the calculation using AHP, Work Accident (HR2) has been identified as the most vulnerable risk among others risk factors.
\end{abstract}

Keywords: risk management; logistic management; analytical hierarchy process 


\section{INTRODUCTION}

Risk Management in Indonesia State Owned Enterprise, is conducted to prevent the decline in investor confidence, and also to prevent the company from entangled in legal cases. Requirements Regarding Risk Management applicable to SOEs is set forth in the Regulation of the Minister of StateOwned Enterprises Number: Per-01/MBU/2011 on the Implementation of Good Corporate Governance (Madjidi, 2013).

Various professional organizations and practitioners in the field of risk management, then issued various standards to improve and improve the quality of risk management implementation, such as COSO (Committee of sponsoring Organization of the Treadway Commission), AS NZS which adopted by ISO for ISO 31000, RIMS, etc (Ansori, 2016).

The implementation of Risk Management in SOEs began in the early 2000s, which began with major state-owned companies such as Pertamina, Bank Mandiri, BRI, PLN, after which almost all SOEs implemented risk management as management awareness and stakeholder awareness increased.

In the internal of the Company, already has Management Risk Division, to implement Risk Management, in which assess business risks on the internal business process, and also for every project held by corporation. In terms of logistic department, its business risks haven't been assessed spesifically. Implementation of risk management in Company supporting units, is done as a risk assessment for work projects only, they have not specifically assessed the risk of business processes as a whole. Level of risks in each activity does not take into account of the preparation of the work manual (Standard Operating Procedure).

In carrying out its main task, logistics management is carried out by the logistics department; with the scope of work monitoring and evaluating the implementation of material management policies and logistics management to maintain the availability of materials and logistics, in order to create reliability and efficiency in the transmission of electricity power.

In practice, logistic department faces various operational challenges, including:

Coordination of materials supply with related department,

Distribution of materials to user,

Work safety related logistic,

Safeguarding the company's assets (materials inventory and spare material, and not operating fixed assets).

The role of logistics functions in the provision of materials is the recipient of goods in accordance with contract documents that received from the procurement department, as well as preparing the necessary facilities and infrastructure, plan the schedule and resources required for the receipt of the goods. In the process of receiving the goods, its also conducted a physical examination (visual) and completeness of documents that accompany the arrival of goods. Whereas, in case of quality inspection of goods, will be conducted by the Quality Product Examining Team which stated in the Minutes of Examination.

There were few events that create loss for the company from logistic process, such as loss of material, and material damage caused by failure in material handling. Such conditions, leading to unavailability of materials, which become business issue in this study, that may hold up other business processes, such as power electrical transmission interruptions handling, and transmission construction projects.

From the FGD process with logistic department, we found that unavailability of materials is caused by three factors, shown by table below.

Table 1. Unavailability of Materials Factors

\begin{tabular}{|c|c|c|}
\hline No & Factors & Description \\
\hline 1 & Loss of materials & Loss off materials can occur due to low security, human fraud, loss on shipping \\
\hline 2 & Materials Damage & $\begin{array}{l}\text { Materials damage can occur due to damage in shipping, damage in storage, and } \\
\text { obsolete materials }\end{array}$ \\
\hline 3 & Procurement Issue & $\begin{array}{l}\text { Improper material planning could lead to failure on material specification, and } \\
\text { also unclear project location could lead to failure on material shipping } \\
\text { destination, these failures lead to procurement issue, as well as the length of } \\
\text { time required due to procurement process delays }\end{array}$ \\
\hline
\end{tabular}


Factors and causes identified in the FGD, are some risks arising from logistic business process which has not been prepared for its risks mitigation yet. Logistic department hasn't been conducted a risk assesment to its business process, hence there are no initial identification of events that may pose a business risk to the company. Therefore, any event that could cause loss to the company has not been prepared for mitigation.

Logistic department faces several potential risks that must be mitigated by, such as financial risks that resulted in additional costs and loss of revenue, and operational risks that arising from management logistics operations if cannot be done properly. The risk of material loss, material damage, labor fraud and workplace accidents are some examples of possible risks in logistic department.

Therefore, in carrying out its duties to maintain the availability of materials and logistics, logistic department needs to do a risk management process to identify and evaluate the risks that may occur.

\section{METHOD}

This study will use International Risk Management Standard AS/NZS ISO 31000:2009, to assess the risk on Logistic Department. Risk is defined as the 'effect of uncertainty on objectives' (AS/NZS ISO 31000:2009). The objectives can be financial, health and safety, environmental and so on. The risk management process involves the following steps, as given in ISO 31000:2009:

setting objectives and establishing the context of the risk assessment;

identifying the risks;

analysing the risks to determine the level of risk, which is defined as the combination of the consequences and likelihood of the risk;

evaluating the risk, to decide if a risk is acceptable, tolerable or intolerable / unacceptable;

treating the risks, focusing on those risks which are intolerable; and

monitoring and review, to continuously refine and improve the assessment and risk treatments (Rollason, 2010).

The central spine of the risk management process is concerned with preparing for and then conducting risk assessment leading, as necessary, to risk treatment. The process starts through defining what the organization wants to achieve and the external and internal factors that may influence success in achieving those objectives. This step is called establishing the context and is an essential precursor to risk identification (Purdy, 2010).

This research uses FGD method to explore the business issue, risk identification, risk treatment, and implementation plan. Focus grup discussion is frequently used used as a qualitative approach to gain an in-depth understanding of social issues. The method aims to obtain data from a purposely selected group of individuals rather than from a statistically representative sample of a broader population (Tobias O.Nyumba, 2017).

According to (Casey, 2000), focus group provides "a more natural environment than that of individual interview because participants are influencing and influenced by others-just as they are in real life". Focus group interview aims at collecting high-quality data in a social context (Patton, 2002), which primarily help understand a specific problem from the viewpoint of the participants of research (Khan, 1992).

To explore the business issue, this study conducted five focus grups discussion, which involved six participants from logistic department and accounting department. The FGD session starts from discussed work flow on logistic department and defining SWOT analysis base on practical experience and work process. Next session of FGD is to identified common issues and problems happened in logistic process.

Entering the risk assessment stage of this study, again conducted FGDs to collect identified risks from business processes undertaken by the logistics department, which resulted the risk identification. At the next step of risk assesment process, the FGD was conducted to give judgement on the identified risks by its impact and likelihood according to the panelists experience and opinions. This FGD was resulted on collecting data to calculate risk priority by the AHP process.

Treatment of risks to be taken was determined from the FGD with the panelists, hence the panelists in which they are the practioners of the business process in logistic, could develop treatment 
options which are suitable to the company conditions. And the implementation plan developed from the risk treatments stage, were constructed in the next FGD.

Analysis of business situation on logistic deparment, will be explored by using business process analysis and SWOT analysis, to determine the strengths, weakdesses, opportunities and threats from logistic department, to be further examine risk management.

The Risk Management Process will refer to International Risk Management Standard AS/NZS ISO 31000:2009, which provide set of principles and guidelines to implement risk management. Based on ISO 31000, Risk Management process is an systematic application of management policies, procedures and practices to the activities of communicating, consulting, establishing the context, and identifying, analyzing, evaluating, treating, monitoring and reviewing risk, that shown in figure 1, which will be used in this study to develop risk management for logistic department.

This study will use The Analytic Hierarchy Proses (AHP) developed by Saaty, which is a robust and flexible multi criteria decision analysis methodology. Analytic hierarchy process (AHP) is a powerful method to solve complex decision problems. Any complex problem can be decomposed into several sub-problems using AHP in terms of hierarchical levels where each level represents a set of criteria or attributes relative to each sub-problem (Saaty, 2008).

Through AHP, the importance of several attributes is obtained from a process of paired comparison. Once the hierarchy has been constructed, begins the prioritization procedure to determine the relative importance of the element in each level of hierarchy. Pairwise comparison data obtained from questionner of interview in the department and supporting unit.

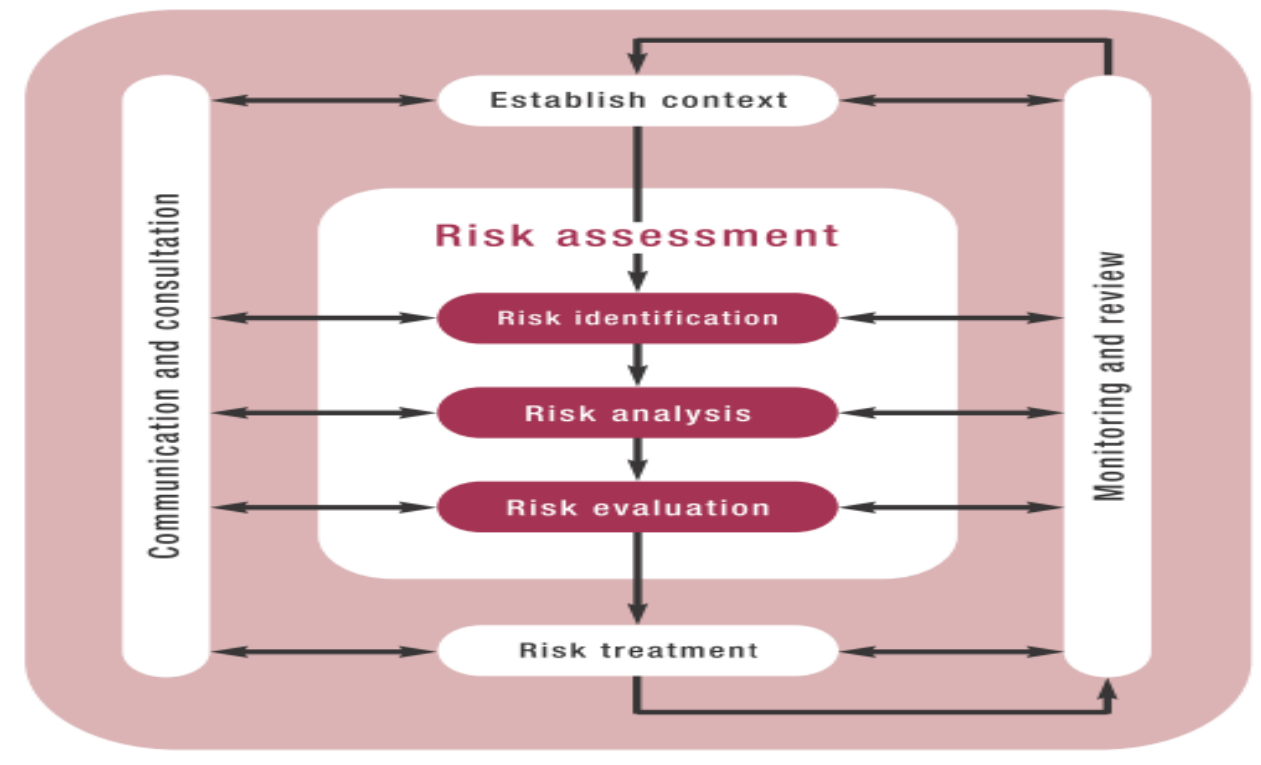

Figure 1. Risk Management Process ISO 31000:2009

(Source: Literature Review (AIRMIC, ALARM, \& IRM, 2010; ISO, 2009; Purdy, 2010

Final stage would be the implemantation which consist of monitoring and review stage. The implementation stage is carried out to ensure that risk planning and mitigation have been carried out and monitored, so that company would be ready to face future challenge in the business.

Analysis of Business Proses in Logistic Departement

The logistics department is involved in the following corporate activities:

Procurement department

Contract review and administration

Product and services quality approval team

Accounting department

Construction department

Supplier materials

Transmission maintenance department 
Supporting unit

Warehouse PIC

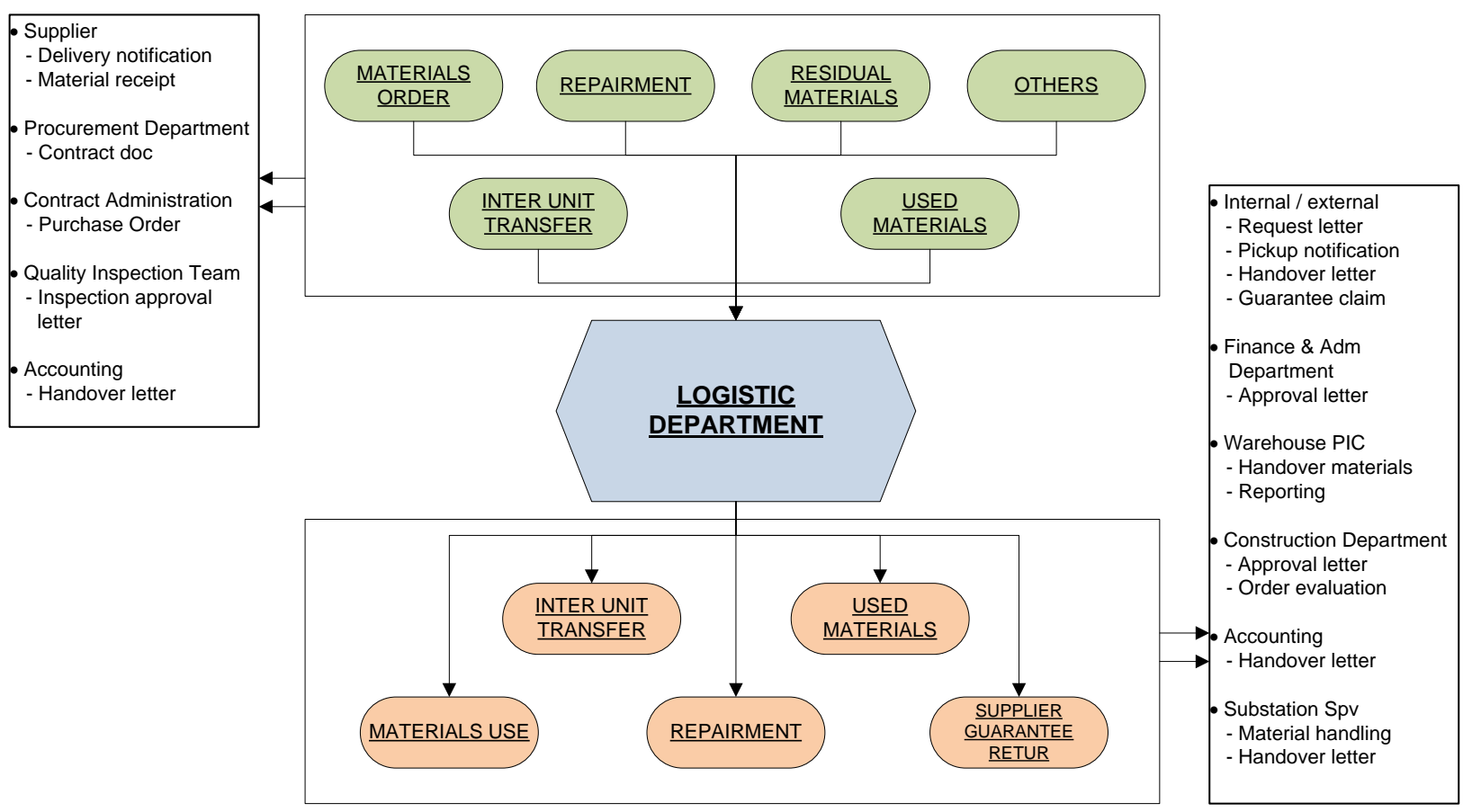

Figure 2. Logistic Department Business Process

(Source : Internal Operation Manual)

Logistic department carry out tasks in acceptance and disbursement of materials. Materials coming to logistic department and stored in the warehouse located on each supporting unit, which could come from several sources, that are:

Material Orders from supplier, processed by procurement department

Repairment of broken asset (materials)

Residual materials

Used materials

Inter unit transfers of materials

Other sources, such as: grant from other company, residual material from construction project division.

And disbursement of matrials should be requested and sent to:

Inter unit transfers

Inter unit outside company

Repairment

Not operating fix asset

Return to supplier in case of guarantee claim

Materials to be use by others department

Materials acceptance process, should involve Quality Assurance Team that refers to the project contract, with the task of ensuring:

Quantity and quality of materials

Operational test

System test

Doccument completeness

\section{Business process analysis using SWOT}

Based on the business processes of logistic department, we do a SWOT analysis to analyze the business situation, and as a guide in identifying risks, because this method involves an assessment of 
the Strengths, Weaknesses, Opportunities and Threats of the business process, as shown on figure 3 below.

\begin{tabular}{ll}
\hline - Each supporting unit has its own warehouse up to the sub-unit level \\
- Most of the warehouse employees are highly experienced seniors \\
- Already has a warehouse guidance set forth in TUG \\
- Warehouse capacity, often does not meet to accommodate inventory \\
- Warehouse management is still not well implemented \\
- There is a void or excess stock of inventory materials \\
- Spatial arrangement and location of warehouse not yet optimal \\
- There is no notification of inventory amount to user \\
- Lack of warehouse staff \\
- Inaccurate entry and exit material entry system \\
- Implementation of logistic and warehouse management integrated \\
\\
with SCM, can ensure the supply of inventory required, so that \\
- Pusiness processes can run faster \\
- the mation of integrated applications between warehouses, users of \\
- Occurrence of work accident \\
- material void could prevents the handling of transmission \\
interruptions \\
- Material damage causes asset loss \\
- Delay in material procurement
\end{tabular}

Figure 3. SWOT Analysis of Logistic Department

(Source :Analysis from FGD)

\section{Business Issues Analysis}

The business issues that will be the object of this study are :

Materials damage in the warehouse storage

Loss of assets (materials)

These issues are cause of Unavailibility of materials (material out-of stock), which is the main issue in logistic department. And by doing root cause analysis of the main issue, we discover another business issue which is 'procurement issues'.

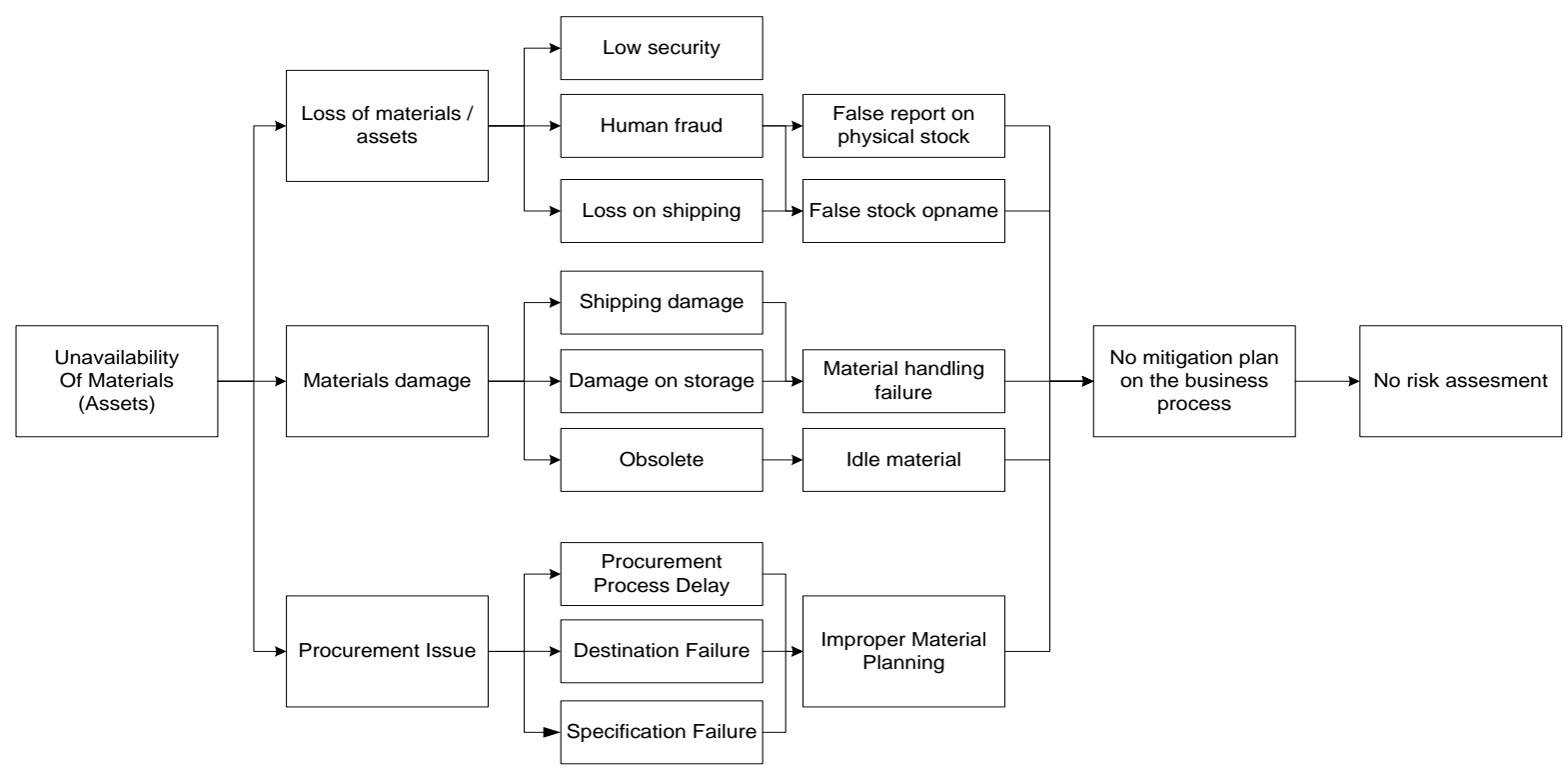

Figure 4. Cause Mapping from Logistic department main business issue

(Source : Analysis from FGD) 
Figure 4. shown the Cause Mapping from logistic department, with the main issue Unavailability of materials (assets/materials out of stocks), which caused by loss of materials/assets, materials damage, procurement issues. The symptoms shown, can be mitigated if there is risk mitigation plan in the business process. Therefore, it is necessary to conduct risk management for logistic department business process.

Cause mapping is a structured approach to solving problems base on facts and data with supporting evidence. When the process doesn't produce the desired results, start the Cause Mapping process. Find and define a problem using process map, solve it with Cause map, and use those solutions (Mark, 2005).

\section{Risk Management Process}

Establish The context

Context of risk management process in this study is to assess the risk in logistic department of to solve business issue discovered, and also to give comprehensive identification of risk in logistic business prosess.

Risk Assessment

Risk assesment is an overall process of risk identification, risk analysis and risk evaluation (ISO, 2009). The risk assessment process is well suited to a structured and systematic approach (Legal \& Branch).

\section{Risk Identification}

Process of finding, recognizing and describing risks (ISO, 2009). Risk identification involves the identification of risk sources, events, their causes and their potential consequences (ISO, 2009).

Risk identification in this study, was obtained from several resources:

Business process analysis and SWOT analysis

Risk from another similar research

The identified risk indicators are arranged into risk variables within the scope of the logistic operation, finance, disaster, and human resource. The result of risk identification can be seen in the following table.

Table 2. Risk Identification

\begin{tabular}{|c|c|c|c|}
\hline Categories & Factors & Description & Impacts \\
\hline \multirow{12}{*}{$\begin{array}{l}\text { Operational } \\
\text { (O) }\end{array}$} & $\begin{array}{l}\text { Delivery condition } \\
\text { (O1) }\end{array}$ & $\begin{array}{l}\text { Supplier failure in deadline and/or } \\
\text { quality, wrong destination }\end{array}$ & Materials out of stock \\
\hline & Out of stock (O2) & $\begin{array}{l}\text { Shortage of materials while } \\
\text { needed, wrong specification, wrong } \\
\text { order }\end{array}$ & $\begin{array}{l}\text { Delayed activities for others } \\
\text { department }\end{array}$ \\
\hline & $\begin{array}{l}\text { Storage condition } \\
\text { (O3) }\end{array}$ & Unorganized materials storage & $\begin{array}{l}\text { Delayed in withdrawal } \\
\text { material, obsolete material }\end{array}$ \\
\hline & $\begin{array}{l}\text { Under capacity } \\
\text { (O4) }\end{array}$ & $\begin{array}{l}\text { Inadequate materials storage, } \\
\text { causing relocation materials } \\
\text { outside warehouse }\end{array}$ & Materials damage \\
\hline & $\begin{array}{l}\text { Warehouse } \\
\text { condition (O5) }\end{array}$ & $\begin{array}{l}\text { Poor building and its facilities } \\
\text { conditions }\end{array}$ & $\begin{array}{l}\text { Materials damage, flow of } \\
\text { materials inhibited, work } \\
\text { accident }\end{array}$ \\
\hline & Security (O6) & $\begin{array}{l}\text { Low environment safety at the } \\
\text { warehouse }\end{array}$ & $\begin{array}{l}\text { Loss of materials, material } \\
\text { damage, warehouse damage }\end{array}$ \\
\hline & $\begin{array}{l}\text { Damage shipment } \\
\text { (O7) }\end{array}$ & $\begin{array}{l}\text { Risk of damaged shipment due to } \\
\text { non-optimal preparation, unsecured } \\
\text { transport }\end{array}$ & Materials damage and loss \\
\hline & Overstock (O8) & Risk of stock excess related & Materials obsolete \\
\hline & $\begin{array}{l}\text { Compliance breach } \\
\text { (O9) }\end{array}$ & Unlicensed forklift driver & $\begin{array}{l}\text { Materials and warehouse } \\
\text { damage, work accident }\end{array}$ \\
\hline & Receipt error (O10) & $\begin{array}{l}\text { Number of items approved does } \\
\text { not match the quantity shown in } \\
\text { purchase order, quality test failed }\end{array}$ & $\begin{array}{l}\text { Material return to supplier, } \\
\text { delayed in material acceptance }\end{array}$ \\
\hline & $\begin{array}{l}\text { Poor handling } \\
\text { (O11) }\end{array}$ & $\begin{array}{l}\text { Material handling doesn't comply } \\
\text { with its requirement }\end{array}$ & Material damage \\
\hline & Material record & Material record is not accordance & Discrepancy on inventory \\
\hline
\end{tabular}




\begin{tabular}{|c|c|c|c|}
\hline & $(\mathrm{O} 12)$ & to physical stock & $\begin{array}{l}\text { report, failure at costs } \\
\text { accounting }\end{array}$ \\
\hline & Safety (O13) & $\begin{array}{l}\text { Safety devices support do not } \\
\text { available in the warehouse }\end{array}$ & $\begin{array}{l}\text { Damage to warehouse and } \\
\text { materials }\end{array}$ \\
\hline & $\begin{array}{l}\text { Stock control } \\
(\mathrm{O} 14)\end{array}$ & Low frequency on stock control & $\begin{array}{l}\text { Discrepancy on inventory } \\
\text { report }\end{array}$ \\
\hline \multirow{7}{*}{ Finance $(\mathrm{F})$} & Audit risks $(\mathrm{F} 1)$ & Potential finding on audit report & $\begin{array}{l}\text { Deduction on company } \\
\text { performance indicator }\end{array}$ \\
\hline & $\begin{array}{l}\text { Overstock Costs } \\
(\mathrm{F} 2)\end{array}$ & Potential costs over idle stock & High opportunity cost \\
\hline & $\begin{array}{l}\text { Financial } \\
\text { performance }(\mathrm{F} 3)\end{array}$ & $\begin{array}{l}\text { How far materials management } \\
\text { influence financial ratio }\end{array}$ & Decrease on ITO ratio \\
\hline & Extra Costs (F4) & $\begin{array}{l}\text { Replacement cost for missing } \\
\text { material }\end{array}$ & $\begin{array}{l}\text { Increasing extra replacement } \\
\text { costs }\end{array}$ \\
\hline & Idle assets (F5) & $\begin{array}{l}\text { Idle assets caused by bad planning } \\
\text { on material purchase and wrong } \\
\text { spesification }\end{array}$ & $\begin{array}{l}\text { High depreciation costs for } \\
\text { idle assets }\end{array}$ \\
\hline & Receipt delay (F6) & $\begin{array}{l}\text { Late receipt document processing, } \\
\text { include quality assurance check }\end{array}$ & $\begin{array}{l}\text { Delayed in playment, low } \\
\text { budget disbursement }\end{array}$ \\
\hline & $\begin{array}{l}\text { Financial } \\
\text { Statement (F7) }\end{array}$ & Failure in reporting physical stocks & $\begin{array}{l}\text { Low accountability of } \\
\text { financial statement }\end{array}$ \\
\hline \multirow[b]{2}{*}{ Disaster (D) } & Fireworks (D1) & Warehouse building burn & Warehouse damage \\
\hline & $\begin{array}{l}\text { Natural disaster } \\
\text { (D2) }\end{array}$ & Warehouse building damage & Warehouse damage \\
\hline \multirow{5}{*}{$\begin{array}{l}\text { Human } \\
\text { Resources } \\
\text { (HR) }\end{array}$} & $\begin{array}{l}\text { Qualified } \\
\text { employees (HR1) }\end{array}$ & $\begin{array}{l}\text { Difficulty in obtaining qualified } \\
\text { employee }\end{array}$ & Failed HR regeneration \\
\hline & $\begin{array}{l}\text { Work accident } \\
\text { (HR2) }\end{array}$ & $\begin{array}{l}\text { Work accidents caused by human } \\
\text { error }\end{array}$ & $\begin{array}{l}\text { Endanger the safety of the } \\
\text { patients or employees }\end{array}$ \\
\hline & $\begin{array}{l}\text { Performance } \\
\text { measurement } \\
(\mathrm{HR} 3)\end{array}$ & $\begin{array}{l}\text { Improper employee performance } \\
\text { measurement }\end{array}$ & $\begin{array}{l}\text { The quality of employee } \\
\text { performane cannot be known }\end{array}$ \\
\hline & Labor Fraud (HR4) & Fraud caused by employee & Loss of material, extra costs \\
\hline & $\begin{array}{l}\text { Number of } \\
\text { employee (HR5) }\end{array}$ & $\begin{array}{l}\text { Lack of employee in warehouse } \\
\text { handling }\end{array}$ & $\begin{array}{l}\text { Delayed material order } \\
\text { request, unmanaged } \\
\text { warehouse }\end{array}$ \\
\hline
\end{tabular}

Source: Analysis from FGD

From the identification of risks, this study categorized the risks into four categories, operational risks, financial risks, disaster risks, human resource risks, as follows:

Operational risks are risks associated with business process in department, these risks figured event that could happen to stop or prevent the continuity of business process. Conditions related to ship, storage and use of material are factors that arises the operational risks.

Financial risks are risks associated with flow of money, financial statement, accounting systems and financial performance indicator.

Disaster risks are risks associated with damage in the warehouse that could happen from natural disaster and fireworks.

Human resource risks are associated with employee performance, work accident and labour fraud.

Risk Analysis

Risk analysis can be undertaken with varying degrees of detail, depending on the risk, the purpose of the analysis, and the information, data, and resources available. Analysis can be qualitative, semiquantitative, quantitative, or a combination of these, depending on the circumstances (Purdy, 2010)

This study will use The Analytic Hierarchy Proses (AHP) developed by Saaty, Through AHP, the importance of several attributes is obtained from a process of paired comparison. Once the hierarchy has been constructed, begins the prioritization procedure to determine the relative importance of the element in each level of hierarchy.

The Hierarchy of business issue 
The hierarchy tree is developed from risk analysis goal to solve the business issue, which is Risk Assesment of logistic department. From the identification of risk in business process, we found there are four categories, which are operational risks $(\mathrm{O})$, financial risks $(\mathrm{F})$, disaster risks $(\mathrm{D})$, human resource risks (HR).

\section{RESULT AND ANALYSIS}

Risk Analysis Result

At this stage weighting is done on criteria in risk factor assessment on logistic department of this electricity company, the AHP process in this level, which is 1 st level of the hierarchy, generate the weight or coefficient importance of each risk, which obtained from pairwised comparison questionnaire from FGD panel and processed with Expert Choice software.

Table 3. AHP Result for level 1 Hierarchy

\begin{tabular}{clc} 
Risk Factor & \multicolumn{1}{c}{ Risk Criteria } & Weight \\
\hline HR & Human Resources & 0,394 \\
O & Operational & 0,294 \\
F & Financial & 0,178 \\
D & Disaster & 0,135 \\
\hline
\end{tabular}

Source: Analysis

On the basis of this result shown in tabel 3., the expert panel concluded that Human Resources is the major factor for unavailability of materials, this result may come up as result of their experiences in logistic department.

The next stage is the weighting of the 28 sub-criteria in the assessment of risk factors identified. Pairwised comparison of the sub-criteria is done in the scope of each risk criteria and generating Local Percentage (LP). Measuring weight of each sub-criteria in order to determine rank of all sub-criteria is shown by Global Percentage (GP) which generated from weighting each sub-criterias across all criteria. Table 4. below, shown weighted summary of each sub-criteria with respect to the overall goal.

Table 4. AHP Result for Level 2 Hierarchy

\begin{tabular}{|c|c|c|c|c|c|c|}
\hline \multirow{2}{*}{ Risk Criteria } & \multirow{2}{*}{ Weight } & \multirow{2}{*}{$\begin{array}{c}\text { Risk Sub- } \\
\text { Criteria }\end{array}$} & \multicolumn{2}{|c|}{ Weight } & \multicolumn{2}{|c|}{ Rank } \\
\hline & & & LP & GP & LR & GR \\
\hline \multirow{5}{*}{ Human Resources [HR] } & \multirow{5}{*}{0,394} & Work accident & 0,374 & 0.147 & 1 & 1 \\
\hline & & $\begin{array}{l}\text { Qualified } \\
\text { employees }\end{array}$ & 0,216 & 0.085 & 2 & 3 \\
\hline & & Labor Fraud & 0,214 & 0.084 & 3 & 4 \\
\hline & & $\begin{array}{l}\text { Performance } \\
\text { measurement }\end{array}$ & 0,115 & 0.045 & 4 & 7 \\
\hline & & $\begin{array}{l}\text { Number of } \\
\text { employee }\end{array}$ & 0,081 & 0.032 & 5 & 9 \\
\hline \multirow{14}{*}{ Operational $[\mathrm{O}]$} & \multirow{14}{*}{0,294} & Safety & 0,209 & 0.061 & 1 & 5 \\
\hline & & Poor handling & 0,089 & 0.026 & 2 & 11 \\
\hline & & Out of stock & 0,088 & 0,026 & 3 & 12 \\
\hline & & $\begin{array}{l}\text { Compliance } \\
\text { breach }\end{array}$ & 0,088 & 0,026 & 4 & 13 \\
\hline & & Receipt error & 0,073 & 0,021 & 5 & 15 \\
\hline & & Stock control & 0,067 & 0,020 & 6 & 18 \\
\hline & & Security & 0,065 & 0,019 & 7 & 19 \\
\hline & & Damage shipment & 0,062 & 0,018 & 8 & 20 \\
\hline & & Material record & 0,056 & 0,016 & 9 & 22 \\
\hline & & Storage condition & 0,049 & 0,014 & 10 & 23 \\
\hline & & $\begin{array}{l}\text { Delivery } \\
\text { Condition }\end{array}$ & 0,043 & 0,013 & 11 & 25 \\
\hline & & Overstock & 0,041 & 0,012 & 12 & 21 \\
\hline & & Under capacity & 0,035 & 0,010 & 13 & 27 \\
\hline & & $\begin{array}{l}\text { Warehouse } \\
\text { condition }\end{array}$ & 0,035 & 0,010 & 14 & 28 \\
\hline Financial & 0,178 & Financial & 0,264 & 0,047 & 1 & 6 \\
\hline
\end{tabular}




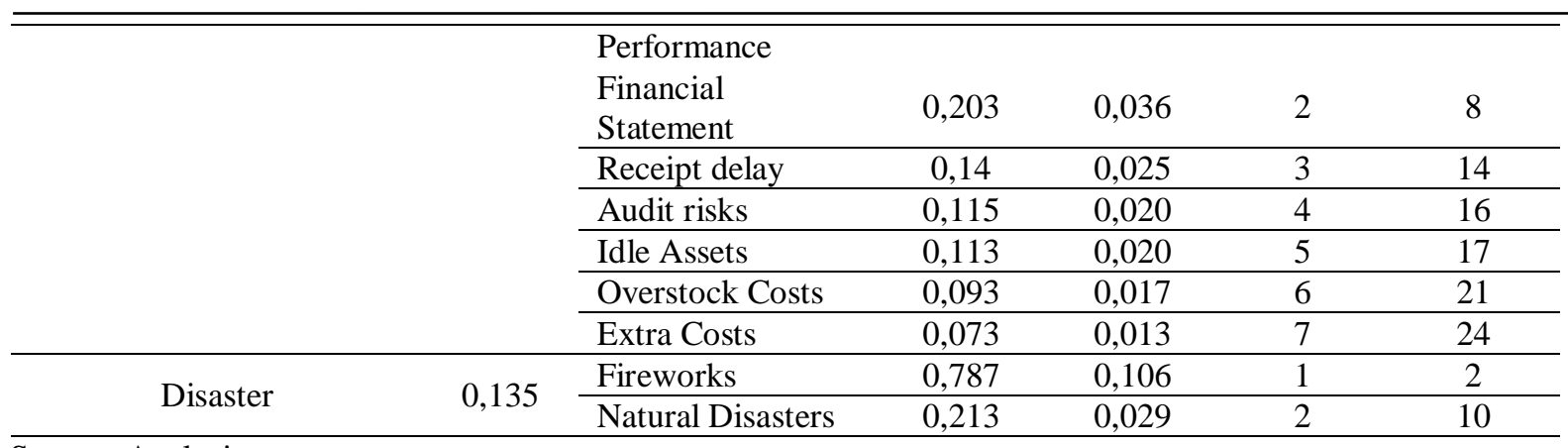

\section{Source: Analysis}

From Table 4. above, the expert panel concluded that Work accident and Safety, are major subcriteria in risk assesment of logistic department. Those sub-criterias also have importants role in company performance, which also stated in Company Key Performance Indicator, that categorized as a minus point (negative impact) to overall score of KPI, therefore they became most important risk factors to be assessed.

\section{Risk Assessment Matrix}

Risk assessment matrix is a tool to analyze risk and identify the risk size, alos measure how the risk can be controlled or not. This matrix has two dimension, which combining potential impact of the event of risk and the likelihood of the event happen in the such condition. Risk matrix describes the position of each risk factor in accordance with their impact and likelihood.

In this study, level of risks are categorized to: low risk, very low risk, moderate risk, high risk, very high risk; which adjusted to the dimension of risk matrix (likelihood and impact). These parameters generated from the likelihood and impact judgmented by the panel, as outlined in the questionnaire.

Table 5. Risk level for impact

\begin{tabular}{lcl}
\hline Level & Numeric & Description \\
\hline Very low impact & 1 & not significant to project \\
low impact & 2 & can be managed without mitigation \\
Medium impact & 3 & may require mitigation \\
High impact & 4 & significant impact on cost / schedule. \\
Very High impact & 5 & The most adverse risks that lead to high amount of losses \\
\hline
\end{tabular}

Source: Analysis from FGD

Table 6. Risk level for likelihood

\begin{tabular}{lcl}
\hline Level & Numeric & Description \\
\hline Very low probability & 1 & not worth considering \\
Low probability & 2 & Unlikely to occur \\
Medium probability & 3 & realistic chance of occurrence \\
High probability & 4 & likely to occur \\
Very high proability & 5 & almost certain to occur \\
\hline
\end{tabular}

Source: Analysis from FGD 
Table 7. AHP Result for Risk Factor Impact Level

\begin{tabular}{|c|c|c|c|c|c|c|c|c|}
\hline \multirow[b]{2}{*}{ Factors } & \multirow{2}{*}{$\begin{array}{c}\text { Global } \\
\text { percentage }\end{array}$} & \multirow[b]{2}{*}{ Sub-factors } & \multirow{2}{*}{$\begin{array}{c}\text { Global } \\
\text { percentage }\end{array}$} & \multicolumn{5}{|c|}{ Level of risk (impact) } \\
\hline & & & & Very Low & Low & Medium & High & Very High \\
\hline \multirow{14}{*}{ Operational } & \multirow{14}{*}{0.294} & Delivery condition (01) & 0.013 & 0.001 & 0.002 & 0.002 & 0.005 & 0.004 \\
\hline & & Out of stock (O2) & 0.026 & 0.002 & 0.003 & 0.005 & 0.010 & 0.006 \\
\hline & & Storage condition (O3) & 0.014 & 0.002 & 0.001 & 0.004 & 0.005 & 0.003 \\
\hline & & Over capacity (O4) & 0.010 & 0.001 & 0.001 & 0.002 & 0.005 & 0.002 \\
\hline & & Warehouse condition (05) & 0.010 & 0.001 & 0.002 & 0.002 & 0.004 & 0.002 \\
\hline & & Security (06) & 0.019 & 0.001 & 0.003 & 0.003 & 0.009 & 0.003 \\
\hline & & Damage shipment (07) & 0.018 & 0.001 & 0.002 & 0.003 & 0.009 & 0.003 \\
\hline & & Overstock (O8) & 0.012 & 0.001 & 0.001 & 0.002 & 0.006 & 0.002 \\
\hline & & Compliance breach (09) & 0.026 & 0.002 & 0.002 & 0.007 & 0.012 & 0.004 \\
\hline & & Receipt error (010) & 0.021 & 0.001 & 0.002 & 0.005 & 0.010 & 0.003 \\
\hline & & Poor handling (011) & 0.026 & 0.001 & 0.003 & 0.003 & 0.015 & 0.004 \\
\hline & & Material record (012) & 0.016 & 0.001 & 0.001 & 0.004 & 0.008 & 0.003 \\
\hline & & Safety (013) & 0.061 & 0.004 & 0.005 & 0.016 & 0.023 & 0.014 \\
\hline & & Stock control (014) & 0.020 & 0.001 & 0.002 & 0.005 & 0.009 & 0.003 \\
\hline \multirow{7}{*}{ Financial } & \multirow{7}{*}{0.178} & Audit risks (F1) & 0.020 & 0.001 & 0.004 & 0.004 & 0.008 & 0.003 \\
\hline & & Overstock Costs (F2) & 0.017 & 0.001 & 0.002 & 0.004 & 0.006 & 0.003 \\
\hline & & Financial performance (F3) & 0.047 & 0.005 & 0.007 & 0.012 & 0.011 & 0.013 \\
\hline & & Extra Costs (F4) & 0.013 & 0.001 & 0.004 & 0.002 & 0.004 & 0.002 \\
\hline & & Idle Assets (F5) & 0.020 & 0.001 & 0.002 & 0.005 & 0.009 & 0.003 \\
\hline & & Receipt delay (F6) & 0.025 & 0.003 & 0.002 & 0.005 & 0.010 & 0.006 \\
\hline & & Financial Statement (F7) & 0.036 & 0.003 & 0.005 & 0.009 & 0.010 & 0.009 \\
\hline \multirow{2}{*}{ Disaster } & \multirow{2}{*}{0.135} & Fireworks (D1) & 0.106 & 0.007 & 0.020 & 0.012 & 0.023 & 0.044 \\
\hline & & Natural disaster (D2) & 0.029 & 0.002 & 0.004 & 0.005 & 0.006 & 0.012 \\
\hline \multirow{5}{*}{$\begin{array}{l}\text { Human } \\
\text { Resource }\end{array}$} & \multirow{5}{*}{0.394} & Qualified employees (HR1) & 0.085 & 0.005 & 0.010 & 0.014 & 0.041 & 0.014 \\
\hline & & Work accident (HR2) & 0.147 & 0.016 & 0.012 & 0.027 & 0.058 & 0.035 \\
\hline & & Performance measurement (HR3) & 0.045 & 0.003 & 0.004 & 0.016 & 0.016 & 0.008 \\
\hline & & Labor Fraud (HR4) & 0.084 & 0.009 & 0.016 & 0.010 & 0.033 & 0.016 \\
\hline & & Number of employee (HR5) & 0.032 & 0.003 & 0.003 & 0.011 & 0.006 & 0.008 \\
\hline \multicolumn{4}{|c|}{ Impact level of risk } & 0.079 & 0.126 & 0.196 & 0.366 & 0.233 \\
\hline
\end{tabular}

Source: AHP Calculation

The impact of each risk factors which shown in table 7. given the outcome of the subfactors with respect to the overall goal, shown in columns 5-9. The results of the AHP process show judgments from panelists that risks in logistic departmement business process give high impact to the company risk with impact level of 0.366 .

From the AHP Result for impact level of risk, Work Accident [HR2] is a subfactor that has the greatest impact on the risk of business processes in logistic department, with a high level of impact 0.058, followed by Fireworks [D1] 0.044 which give very high level on impact of company risk. 
Risk Management of Logistic Department Of Electricity Company;

Erdiyan Krisnadi Hasda, Erman Sumirat

Table 8. AHP Result for Risk Factor Likelihood Level

\begin{tabular}{|c|c|c|c|c|c|c|c|}
\hline \multirow{2}{*}{ Factors } & \multirow{2}{*}{$\begin{array}{c}\text { Global } \\
\text { percenta }\end{array}$} & \multirow{2}{*}{ Sub-factors } & \multicolumn{5}{|c|}{ Level of risk (likelihood) } \\
\hline & & & Very Low & Low & Medium & High & Very High \\
\hline \multirow{14}{*}{ Operational } & \multirow{14}{*}{0.294} & Delivery condition (01) & 0.001 & 0.002 & 0.002 & 0.005 & 0.003 \\
\hline & & Out of stock (O2) & 0.002 & 0.003 & 0.012 & 0.005 & 0.005 \\
\hline & & Storage condition (O3) & 0.002 & 0.001 & 0.005 & 0.004 & 0.003 \\
\hline & & Over capacity (O4) & 0.001 & 0.001 & 0.001 & 0.005 & 0.003 \\
\hline & & Warehouse condition (05) & 0.001 & 0.003 & 0.002 & 0.002 & 0.003 \\
\hline & & Security (06) & 0.001 & 0.006 & 0.004 & 0.004 & 0.004 \\
\hline & & Damage shipment (07) & 0.002 & 0.006 & 0.004 & 0.003 & 0.004 \\
\hline & & Overstock (08) & 0.001 & 0.003 & 0.001 & 0.004 & 0.002 \\
\hline & & Compliance breach (09) & 0.003 & 0.002 & 0.004 & 0.012 & 0.004 \\
\hline & & Receipt error (010) & 0.003 & 0.005 & 0.005 & 0.005 & 0.004 \\
\hline & & Poor handling (011) & 0.002 & 0.003 & 0.012 & 0.005 & 0.004 \\
\hline & & Material record (012) & 0.001 & 0.002 & 0.004 & 0.006 & 0.003 \\
\hline & & Safety (013) & 0.004 & 0.012 & 0.020 & 0.011 & 0.014 \\
\hline & & Stock control (014) & 0.003 & 0.002 & 0.008 & 0.003 & 0.004 \\
\hline \multirow{7}{*}{ Financial } & \multirow{7}{*}{0.178} & Audit risks (F1) & 0.001 & 0.004 & 0.005 & 0.004 & 0.005 \\
\hline & & Overstock Costs (F2) & 0.001 & 0.003 & 0.005 & 0.003 & 0.003 \\
\hline & & Financial performance (F3) & 0.005 & 0.007 & 0.012 & 0.014 & 0.009 \\
\hline & & Extra Costs (F4) & 0.001 & 0.007 & 0.001 & 0.002 & 0.002 \\
\hline & & Idle Assets (F5) & 0.001 & 0.004 & 0.008 & 0.003 & 0.004 \\
\hline & & Receipt delay (F6) & 0.002 & 0.002 & 0.014 & 0.003 & 0.004 \\
\hline & & Financial Statement (F7) & 0.002 & 0.004 & 0.020 & 0.004 & 0.006 \\
\hline \multirow{2}{*}{ Disaster } & \multirow{2}{*}{0.135} & Fireworks (D1) & 0.058 & 0.006 & 0.012 & 0.013 & 0.017 \\
\hline & & Natural disaster (D2) & 0.005 & 0.006 & 0.006 & 0.005 & 0.006 \\
\hline \multirow{5}{*}{$\begin{array}{l}\text { Human } \\
\text { Resource }\end{array}$} & \multirow{5}{*}{0.394} & Qualified employees (HR1) & 0.005 & 0.008 & 0.025 & 0.034 & 0.012 \\
\hline & & Work accident (HR2) & 0.028 & 0.020 & 0.036 & 0.032 & 0.031 \\
\hline & & Performance measurement (HR3) & 0.003 & 0.006 & 0.020 & 0.008 & 0.008 \\
\hline & & Labor Fraud (HR4) & 0.016 & 0.025 & 0.012 & 0.013 & 0.018 \\
\hline & & Number of employee (HR5) & 0.003 & 0.002 & 0.003 & 0.019 & 0.005 \\
\hline \multicolumn{3}{|c|}{ Likelihood level of risk } & 0.158 & 0.156 & 0.267 & 0.232 & 0.189 \\
\hline
\end{tabular}

Source: AHP Calculation

From table 8. above, the risk factor Work Accident (HR2) has been identified as the most vulnerable for the logistic department business process as it has high probability of occurrence among risk sub-factors, with very high level of likelihood at 0.031 .

Based on above result of impact and likelihood level, the next step is to form the risk matrix. Score for each sub-factor in the matrix, obtained from calculation of its likelihood and impact level at its highest point, which generated from combination data of the panel (expert judgement).

Table 9. Impact and Likelihood Level of Risks

\begin{tabular}{lll}
\hline \multirow{2}{*}{ Sub-factors } & \multicolumn{2}{c}{ Level of Risk } \\
\cline { 2 - 3 } & Impact & Likelihood \\
\hline Delivery condition (O1) & High & High \\
Out of stock / Unordered material (O2) & High & Medium \\
Storage condition (O3) & High & Medium \\
Under capacity (O4) & High & High \\
Warehouse condition (O5) & High & Very High \\
Security (O6) & High & Low \\
Damage shipment (O7) & High & Low \\
Overstock (O8) & High & High \\
Compliance breach (O9) & High & High \\
Receipt error (O10) & High & Medium \\
Poor handling (O11) & High & Medium \\
\hline
\end{tabular}




\begin{tabular}{lll}
\hline Material record (O12) & High & High \\
Safety (O13) & High & Medium \\
Stock control (O14) & High & Medium \\
\hline Audit risks (F1) & High & Medium \\
Overstock Costs (F2) & High & Medium \\
Financial performance (F3) & Very High & High \\
Extra Costs (F4) & High & Low \\
Idle Assets (F5) & High & Medium \\
Receipt delay (F6) & High & Medium \\
Financial Statement (F7) & High & Medium \\
\hline Fireworks (D1) & Very High & Very Low \\
Natural disaster (D2) & Very High & Low \\
\hline Qualified employees (HR1) & High & High \\
Work accident (HR2) & High & Medium \\
Performance measurement (HR3) & High & Medium \\
Labor Fraud (HR4) & High & Low \\
Number of employee (HR5) & Medium & High \\
\hline Source: Researh Analyis
\end{tabular}

Source: Research Analysis

\section{CONCLUSION}

Table 10. shown summary of impact and likelihood level of risk, which will be mapped on the risk matrix below.

Table 10. Risk Matrix

\begin{tabular}{|c|c|c|c|c|c|}
\hline & \multicolumn{5}{|c|}{ IMPACT } \\
\hline LIKELIHOOD & Very low (1) & Low (2) & Medium (3) & High (4) & Very High (5) \\
\hline Very Low (1) & Low & Low & Low & Low & D1 \\
\hline Low (2) & Low & Low & Low & $\begin{array}{l}\text { O6; O7; F4; } \\
\text { HR4 }\end{array}$ & D2 \\
\hline Medium (3) & Low & Low & Medium & $\begin{array}{l}\text { O2; O3; O10; } \\
\text { O11; O13; } \\
\text { O14; F1; F2; } \\
\text { F5; F6; F7; } \\
\text { HR2; HR3 }\end{array}$ & Medium \\
\hline High (4) & Low & Medium & HR5 & $\begin{array}{l}\mathrm{O} 1 ; \mathrm{O} 4 ; \mathrm{O} 8 ; \\
\mathrm{O} 9 ; \mathrm{O} 12 ; \mathrm{HR} 1\end{array}$ & F3 \\
\hline Very High(5) & Low & Medium & Medium & $\mathrm{O} 5$ & Extreme \\
\hline
\end{tabular}

Source: Research Analysis

Table 11. Definition of Risk Levels

\begin{tabular}{cl}
\hline Risk Level & \multicolumn{1}{c}{ Definition } \\
\hline Low & $\begin{array}{l}\text { The risk categorized as negligible, but it must be under review and } \\
\text { control. }\end{array}$ \\
\hline Medium & $\begin{array}{l}\text { The risk need to be eliminated and controlled, even its not necessary } \\
\text { to do so. }\end{array}$ \\
\hline High & $\begin{array}{l}\text { The risk could endanger the company, therefore action plan to control } \\
\text { and eliminate the risk need to be taken immediately. }\end{array}$ \\
\hline
\end{tabular}


From the table 10. and 11., we can concluded that there are some risks need to be controlled and eliminate immediately:

Operational Risks: O1 (Delivery Condition), O4 (Over Capacity), O8 (Overstock), O9 (Compliance Breach), O12 (Material Record), O5 (Warehouse Condition),

Financial Risk: F3 (Financial Performance)

Human Resource Risk: HR1 (Qualified Employee)

\section{Risk Treatment}

According to ISO 31000:2009, risk treatment is the activity of selecting and implementing appropriate control measures to modify the risk. Risk treatment includes as its major element, risk control (or mitigation), but extends further to, for example, risk avoidance, risk transfer and risk financing.

Options for treating risk may involve one or more of the following:

avoiding the risk by deciding not to start or continue with the activity that

gives rise to the risk;

taking or increasing the risk in order to pursue an opportunity;

removing the risk source;

changing the likelihood;

changing the consequences;

sharing the risk (e.g. through contracts, buying insurance);

retaining the risk by informed decision.

When selecting risk treatment options, the organization should consider the values, perceptions and potential involvement of stakeholders and the most appropriate ways to communicate and consult with them. Risk treatments, even if carefully designed and implemented might not produce the expected outcomes and could produce unintended consequences. Monitoring and review need to be an integral part of the risk treatment implementation to give assurance that the different forms of treatment become and remain effective.

Table 12. Risk Treatment Options for Logistic Department

\begin{tabular}{|c|c|c|c|}
\hline Risk Category & Risk Factor & Risk Level & Treatment Option \\
\hline \multirow{6}{*}{ Operational } & Delivery Condition [O1] & High & Sharing the risk \\
\hline & Under Capacity [O4] & High & Change the probability \\
\hline & Overstock [O8] & High & Change the probability \\
\hline & Compliance Breach [O9] & High & Removing the risk source \\
\hline & Material Record [O12] & High & Change the probability \\
\hline & Warehouse Condition [O5] & Very High & Removing the risk source \\
\hline Financial & Financial Performance [F3] & High & Change the probability \\
\hline Human Resource & Qualified Employee [HR1] & High & Change the probability \\
\hline
\end{tabular}

From the FGD with the panel, treatment options for High and Extreme risks mapped in risk matrix, are shown in the table 11. above, the options choosen are sharing the risk, removing the risk source, and change the probability.

\section{REFERENCES}

Ansori, M. (2016). Increasing the Value and Sustainability of BUMN through the Implementation of Enterprise Risk Management (ERM) at the Corporate and Super Holding Levels of the Ministry of BUMN.

Casey, M. \&. (2000). Focus groups: A practical guide for applied research. SAGE Publications.

ISO. (2009). ISO 31000:2009, Risk Management-Principles and Guidelines. Geneva: International Standards Organisation.

Khan, M. E. (1992). Focus groups in tropical diseases. In Research Health Policy and Planning (pp. 5666). Oxford University Press. 
Legal, \& Branch, R. (n.d.). Risk Management Handbook. The University of Adelaide.

Madjidi, I. (2013, February 25). Persyaratan Manajemen Risiko Badan Usaha Milik Negara. Retrieved June 23, 2018, from Persyaratan Manajemen Risiko Badan Usaha Milik Negara: https://idrismadjidi.wordpress.com/2013/02/25/persyaratan-manajemen-risiko-badan-usahamilik-negara/

Mark, G. (2005). Cause Mapping 101. In Fabricating \& Metalworking (p. 68). ABI/INFORM Collection.

Patton, M. (2002). Qualitative Research \& Evaluation Methods. SAGE, 2002.

Purdy, G. (2010). ISO 31000:2009—Setting a New Standard for Risk Management. Risk Analysis.

Rollason, V. (2010). Applying The ISO 31000 Risk Assessment Framework to Coastal Zone Management. Coastal Conference.

Saaty, T. L. (2008). Decision Making With The Analytic Hierarchy Process.

Tobias O.Nyumba, K. W. (2017). The use of focus group discussion methodology: Insights from two decades of application in conservation. Methods in Ecology and Evolution.

\section{AUTHOR PROFILE}

\section{Erdiyan Krisnadi Hasda}

\section{Education}

2016-2018 Master of Business Administration, Sekolah Bisnis dan Manajemen, Institut Teknologi Bandung, GPA 3.76.

1999-2004 Bachelor of Economics, Economic Faculty Parahyangan Catholic University Bandung.

\section{Majoring Management, GPA 2.93 \\ 1996-1999 SMU Negeri 3 Bandung. \\ 1993-1996 SMP Negeri 5 Bandung. \\ 1987-1993 SD BPI Bandung.}

\section{Proffesional Experience}

2007-2018 PT. PLN (Persero).

2004-2007 PT. Bank Syariah Mandiri. 